YEARBOOK

of ANTITRUST

and REGULATORY

STUDIES

www.yars.wz.uw.edu.pl
Peer-reviewed scientific periodical, focusing on legal and economic issues of antitrust and regulation. Creative Commons Attribution-No Derivative Works 3.0 Poland License.

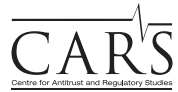

Centre for Antitrust and Regulatory Studies, University of Warsaw, Faculty of Management www.cars.wZ.uw.edu.pl

\title{
Arbitration Agreements and Actions for Antitrust Damages After the CDC Hydrogen Peroxide Judgment
}

\author{
by
}

Katarzyna Sadrak*

\section{CONTENTS}

I. Introduction

II. Arbitrability of EU competition law

1. Development of arbitrability

2. Competition law arbitrable

3. Limitations to arbitrability

4. Conclusions

III. Directive 2014/104/EU and principle of effectiveness of EU law

1. Directive 2014/104/EU

2. Principle of effectiveness of EU law

2.1. Content of the claim for antitrust damages

2.2. Enforcement of the claim for antitrust damages in arbitral proceedings

3. Conclusions

IV. Interpreting the scope of arbitration agreements

1. Impact of the $C D C$ case

1.1. Opinion of Advocate General Jääskinen

1.2. Judgment of the CJ

1.3. Reactions to the $C D C$ case

2. Polish experience in interpreting arbitration clauses

2.1. Legal framework

2.2. Jurisprudence relating to Polish Law on Combating Unfair Competition

2.2.1. Judgment of the Supreme Court on 2 December 2009

2.2.2. Judgment of the Supreme Court on 5 February 2009

* PhD candidate, University of Heidelberg; k.sadrak@gmail.com. Article received: 8.03.2017, accepted: 19.05.2017. 


\subsubsection{Judgment of the Supreme Court on 24 October 2012}

\subsection{Critics}

V. Addressing misconceptions concerning the arbitration of antitrust damages

1. No awareness of the future violation

2. Tort origin of the claim

VI. Conclusions

\section{Abstract}

On May 21st 2015, the Court of Justice of the European Union in CDC Hydrogen Peroxide decided whether the application of jurisdiction clauses in actions for damages impedes the effective enforcement of EU competition law. The CJ stayed silent, however, on how to treat arbitration clauses, which similarly to jurisdiction clauses, exclude a default court jurisdiction. The question of how to interpret arbitration agreements in the event of an antitrust violation and subsequent actions for damages remains thus unanswered. In light of the foreseen increase in private enforcement of EU competition law, this problem gains significance. This is because arbitration agreements may be frequently used to govern commercial relationships between antitrust infringers and their injured direct contractors.

Against this background, the paper aims to analyse the consequences brought about by the existence of arbitration clauses in the event of actions for antitrust damages. It seeks to answer two questions: whether the claims for antitrust damages can be per se arbitrated, and whether the general arbitration clauses used by the parties to regulate their commercial relations cover the actions for antitrust damages. In order to address these problems, the papers draws attention to the CJ's interpretation of jurisdiction clauses and the Polish experience of interpreting the scope of arbitration agreements in the field of unfair competition law. The paper reaches the conclusion that neither the arbitration nor EU law prevent arbitrating actions for antitrust damages. Whether a specific arbitration agreement covers actions for antitrust damages or not can be analyzed only with reference to the will of the parties interpreted under applicable national law. It is believed, however, that there are many reasons to adopt an arbitration-friendly interpretation of vague arbitration agreements.

\section{Résumé}

Le 21 mai 2015, la Cour de justice de l'Union européenne dans l'arrêt $C D C$ Hydrogen Peroxide a statué sur la question de savoir si l'application d'une clause de juridiction lors d'action en dommages et intérêts empêchait une application effective du droit européen de la concurrence. Néanmoins, la Cour de justice est restée muette sur le sort des clauses d'arbitrage qui, à l'instar des clauses de juridiction, excluent la désignation d'une juridiction par défaut. La Cour n'a donc pas tranché sur la manière d'interpréter les accords d'arbitrage dans le cas 
d'une violation du droit de la concurrence et d'actions en dommages intérêts en découlant. Dans l'optique d'une augmentation à prévoir du contentieux du private enforcement, cette question gagne en importance du fait de l'utilisation récurrente des accords d'arbitrage pour régir les relations entre les contrevenants au droit de la concurrence et les parties contractantes lésées.

Dans un tel contexte, cette contribution cherche à analyser les conséquences découlant de l'existence d'une clause d'arbitrage lors d'une action en dommages et intérêts pour violation du droit de la concurrence. Elle cherche à répondre à deux questions: savoir si une action en dommages et intérêts pour violation du droit de la concurrence peut faire l'objet d'une procédure d'arbitrage et déterminer si le recours à la clause général d'arbitrage dans un contrat régulant les relations commerciales entre les parties englobe de telles actions. En vue de résoudre ces problématiques, le présent document attire l'attention du lecteur sur l'interprétation des clauses de juridiction par la CJUE et sur l'interprétation faite par les juridictions polonaises du champ d'application des accords d'arbitrage en matière la concurrence déloyale. Cet article aboutit à la conclusion que ni l'arbitrage ni le droit de l'UE n'empêche le recours à l'arbitrage dans les actions en dommages et intérêts pour infraction aux règles de concurrence. Le fait qu'un accord d'arbitrage spécifique s'applique ou non à ces actions ne peut s'analyser qu'au regard de la volonté des parties interprété en référence au droit national. Cependant, il y a lieu de penser qu'il y a de nombreuses raisons d'adopter une interprétation favorable à l'arbitrage dans les hypothèses d'accords d'arbitrage imprécis.

Key words: arbitrability; arbitration; arbitration agreement; antitrust; competition law; damages; unfair competition.

JEL: K21, K39, K41, K42, K49

\section{Introduction}

Competition law and international arbitration have been seen for many years as being worlds apArticle Arbitration has its origins in private law and materialises the will of parties to depart from the public court jurisdiction to benefit from the adjudication by a mutually agreed arbitrator. In contrast, EU competition law has strong public law features. Its objective is to protect the public good - maintain effective market competition - and its predominant enforcer is a public body, the European Commission. As a result, for many years it was rarely thought to adjudicate competition law matters by means of arbitration (Komninos, 2011, p. 11).

This picture has changed significantly with the development of private competition law enforcement. The milestone was the BRT $v S A B A M$ judgment 
of the ECJ. It confirmed that competition law rules included in the EU Treaties confer on individuals' subjective rights, which national courts must protect $^{1}$. This was confirmed by Article 6 of Regulation 1/2003, providing that national courts have the powers to apply the antitrust law provisions of the Treaty $^{2}$. In particular, national courts have the competence to decide on civil law consequences of antitrust violations (Ritter and Braun, 2005, p. 81-83; Boskowitz, 2009, p. 105-106). In Courage v Crehan, the CJ stated that unjust enrichment and damages may be claimed from those that profited from the violation of antitrust laws ${ }^{3}$. This was developed further in the Directive 2014/104/EU, which created a framework for the facilitated enforcement of actions for damages resulting from the infringement of EU competition law ${ }^{4}$.

The increased private enforcement of EU competition law also challenges arbitrators, since they may face problems of whether and how they should apply competition law in the course of arbitral proceedings. The interplay between EU competition and arbitration law may already have an effect at the very beginning of a dispute. Let us take as an example the recent Commission decision in the truck cartel (2016). The cartel influenced the price of 9 out of every 10 medium and heavy trucks manufactured in Europe for 14 years. There are around 30 million such trucks on European roads. It is expected that a massive amount of claims will be made by truck purchasers for antitrust damages. However, the sales contracts between truck manufacturers and purchasers may contain various jurisdiction and arbitration clauses. Shall then a claim for damages be dealt with before national courts, or before a forum chosen by parties?

The controversy about how to treat arbitration agreements ${ }^{5}$ when actions for antitrust damages are taken has already reached the CJEU. In CDC Hydrogen Peroxide $^{6}$ the Landesgericht Dortmund asked the CJ whether the derogation

1 ECJ judgment of 27.03.1974, Case C-127/73, Belgische Radio en Televisie, ECLI:EU:C:1974:25.

2 Council Regulation (EC) No 1/2003 of 16 December 2002 on the implementation of the rules on competition laid down in Articles 81 and 82 of the Treaty, OJ L 1, 4.1.2003, p. 1-25.

3 CJ judgment of 20.09.2001, Case C-453/99, Courage and Crehan, ECLI:EU:C:2001:465, para. 30-31.

${ }^{4}$ Directive 2014/104/EU of the European Parliament and of the Council of 26 November 2014 on certain rules governing actions for damages under national law for infringements of the competition law provisions of the Member States and of the European Union, OJ L 349, 5.12.2014, p. 1-19.

5 Arbitration agreement is an agreement to designate a particular private arbitrator to resolve the dispute arising out of particular business relationship. Arbitration clause is an expression of such an agreement, usually in the form of a clause in the commercial contract. The paper uses these two terms depending on the context.

${ }^{6}$ CJ judgment of 21.05.2015, Case C-352/13 CDC Hydrogen Peroxide, ECLI:EU:C:2015:335. 
to the jurisdiction rules of Regulation $44 / 2001,{ }^{7}$ by means of jurisdiction and arbitration clauses, has a negative impact on the actions for antitrust damages, and whether it impedes the effectiveness of EU competition law. Although the $\mathrm{CJ}$ analysed private international law aspects of the case, it remained silent regarding arbitration clauses. This has only enhanced doubts about how to treat arbitration agreements and whether to apply the reasoning of the $\mathrm{CJ}$ by analogy to arbitration clauses.

Against this background, the paper aims to shed more light on the interpretation of arbitration agreements in the event of actions taken for antitrust damages. It seeks to answer two questions: whether the claims for antitrust damages can be per se arbitrated (i) and whether the general arbitration clauses used by the parties to regulate their commercial relations 8 cover the actions for antitrust damages (ii). In order to address these questions the paper draws attention to the CJ's interpretation of jurisdiction clauses and the Polish experience of interpreting the scope of arbitration agreements in the field of unfair competition law. The paper reaches the conclusion that neither the arbitration nor EU law prevent arbitrating actions for antitrust damages (i). However, the question of whether a specific arbitration agreement covers actions for antitrust damages or not can only be analysed with reference to the will of the parties interpreted under applicable national law (ii).

The article contributes to the current debate on the arbitrability of EU competition law (Driessen-Reilly, 2015; Geradin \& Villano, 2016; Komninos, 2011; Mourre, 2011; Nazzini, 2008) by rebutting some misconceptions about arbitrating the actions for antitrust damages. It demonstrates that neither the parties' unawareness of anticompetitive behaviour, nor the tort origin of the claim, make it impossible for them to subject the claims for antitrust damages to adjudication of arbitrators. The paper proposes adopting an arbitrationfriendly interpretation of the scope of arbitration agreements with respect to actions for antitrust damages.

To that end, the paper first asks whether actions for antitrust damages are arbitrable (Part II). Second, it discusses whether the principle of effectiveness in EU competition law prevents the arbitrators from dealing with the claims for antitrust damages (Part III). The paper then proceeds to analyse the problem of interpreting the scope of arbitration agreements. It asks what lessons can be drawn from the $C D C$ case before the CJEU, as well as from the Polish experience of dealing with the problem of interpreting the scope of arbitration agreements (Part IV). This leads me to address some common

7 Council Regulation (EC) No 44/2001 of 22 December 2000 on jurisdiction and the recognition and enforcement of judgments in civil and commercial matters, OJ L 12, 16.1.2001, p. 1-23.

${ }^{8}$ For instance, standard arbitration clauses or other broadly formulated arbitration clauses. 
misconceptions on the arbitration of claims for antitrust damages (Part V). Finally, the paper concludes and gives some guidance on how to construct arbitration clauses (Part VI).

\section{Arbitrability of EU competition law}

A discussion of the problem of arbitrating the claims for antitrust damages needs to be commenced with the general problem of the arbitrability of EU competition law. According to UNCITRAL Model Law, arbitrability means that the given subject matter of a dispute is "capable of settlement by means of arbitration" . If the claims for antitrust damages are not arbitrable, they cannot be handled by arbitrators and they are per se excluded from the scope of an arbitration agreement.

\section{Development of arbitrability}

Initially, arbitration was considered as a means to avoid the regular jurisdiction of national courts and the State monopoly to provide justice. It was thus treated with a certain degree of distrust. This applied in particular to requesting arbitrators to resolve disputes relating to the rules of public policy. Among such rules was antitrust law, as expressed by the US Second Circuit in American Safety:

"A claim under the antitrust laws is not merely a private matter. Antitrust violation can affect hundreds of thousands, perhaps millions, of people and inflict staggering economic damage. We do not believe Congress intended such claims to be resolved elsewhere than Courts"10.

Nevertheless, the scope of arbitrable matters has expanded gradually and nowadays encompasses many matters of public interest, e.g. bankruptcy, security, embargo regulations (Mourre, 2011, paras 1-020-024). Under many national laws, arbitrability is linked with the pecuniary or dispositive character of rights, regardless of their qualification as rules of public policy. For instance, in Switzerland, any dispute of a patrimonial character can be subjected to

9 Article 34(b)(i) and 36(b)(i) of UNCITRAL Model Law on International Commercial Arbitration (1985), with amendments as adopted in 2006 ("UNCITRAL Model Law").

${ }^{10}$ American Safety Equipment Corp. v. J. P. Maguire \& Co., Inc., 391 F.2d 821 (2d Cir. 1968). 
arbitration ${ }^{11}$. In other countries, arbitrability is attributed to rights with respect to which the parties can settle ${ }^{12}$ or can freely dispose ${ }^{13}$.

\section{Competition law arbitrability}

Currently, it cannot be doubted that competition law is arbitrable. First, antitrust laws relate to the sphere of commercial activity. Anticompetitive behaviour results in damages that are easily expressed in financial terms. Second, the rights granted to individuals by EU competition rules are dispositive. An injured party can claim compensation for damages sustained as a result of a competition law breach. However, there is nothing preventing the parties to settle the dispute and terminate the conflict without going to court. Indeed, arbitrability of competition law is commonly accepted. The first to adopt it was the US Supreme Court in Mitsubishi Motors Corp. v. Soler Chrysler-Plymouth, Inc.: ${ }^{14}$

"As international trade has expanded in recent decades, so too has the use of international arbitration to resolve disputes arising in the course of that trade. The controversies that international arbitral institutions are called upon to resolve have increased in diversity as well as in complexity; yet the potential of these tribunals for efficient disposition of legal disagreements arising from commercial relations has not yet been tested. If they are to take a central place in the international legal order, national courts will need to shake off the old judicial hostility to arbitration, and also their customary and understandable unwillingness to cede jurisdiction of a claim arising under domestic law to a foreign or transnational tribunal"15.

The Mitsubishi judgment was the turning point. A number of national courts followed this interpretation and explicitly or implicitly accepted the use of arbitration with respect to competition law ${ }^{16}$. Among them was also the

11 E.g. Switzerland (Article 1771 of the Law on Private International Law). Mourre, 2011, para. 1-011.

12 E.g. Belgium (Article 1676 of the Judicial Code and Article 2045 of the Belgian Civil Code), Sweden (Section 1 of the Swedish Arbitration Act), Netherlands (Article 1020-3 of the Dutch Code of Civil Procedure). Mourre, 2011, para. 1-014.

13 E.g. Poland (Article 1557 of the Polish Code of Civil Procedure), Spain (Article 2-1 of the 23 December 2003 Statue), France (Article 2059 of the French Civil Code; not applicable in the context of international arbitration). Mourre, 2011, para. 1-015.

14 Mitsubishi Motors Corp. v. Soler Chrysler-Plymouth, Inc., 473 U.S. 614 (1985).

15 Ibidem.

16 Germany: BGH, Schweißbolzen, KZR 7/65; BGH, Spar, BGHZ 37, 194, 198; BGH Basaltlava, GRUR 1963, 331, 333; BGH, Flußspat, NJW 64, 2343; France: Cour d'appel de Paris, 19 May 1993, Société Labinal v Société Mors \& Westland Aerospace. Italy: Corte d'Appello di Milano, 13 September 2002, Istituto Biochimico Italiano Giovanni Lorenzetti S.p.A. v. Madaus 
CJEU. In Eco Swiss, the judges engaged in a profound analysis of whether the disregard of EU competition provisions should lead to the annulment or refusal to enforce an arbitral award as with a breach of public policy, which already assumes that EU competition law is arbitrable ${ }^{17}$.

\section{Limitations to arbitrability}

The acceptance of the arbitrability of EU competition law has some limits nonetheless. One needs to remember that the adjudicative powers of arbitrators are different to those of competition law enforcers ${ }^{18}$ (Mourre, 2011, paras 1-029, 1-035; Nowaczyk and Syp, 2013, p. 87-88; Bagdziński, 2015, p. 74; Syp, 2015, pp. 74-77). While arbitrators can withdraw civil consequences from antitrust infringement, they cannot use the remedies specific to competition authorities, such as setting fines or declaring state-aid as compatible with an internal market. The role of arbitrators can thus be compared only to the role of national judges.

\section{Conclusions}

The arbitrability of EU competition law holds true for claims for antitrust damages. First, claims for the compensation of antitrust harm concern the application of Article 101 and 102 TFEU, whose arbitrability is undisputed. Second, withdrawing civil consequences from the violation of EU competition law lies certainly within the powers of national judges and arbitrators. From the standpoint of arbitration, there is nothing impeding the handling of claims for antitrust damages.

\section{Directive 2014/104/EU and principle of effectiveness of EU law}

It remains to be analysed whether the claims for antitrust damages can be arbitrated from the perspective of EU competition law. To that aim, this

A.G., n. 2090. Spain: Audiencia Provincial de Madrid, 324/2004, Combustibles del Cantabrico S.L. v. Total; England and Wales: EWHC, ET Plus SA \& Ors v Welter \& Ors, [2005] EWHC 2115 (Comm). See Geradin and Villano, 2016, p. 7-9; Mourre, 2011, para. 1-116-133.

17 CJ judgment of 1.06.1999, Case C-126/97 Eco Swiss, ECLI:EU:C:1999:269.

18 Cour d'appel de Paris, 14 October 1993, Aplix v. Velcro. 
section investigates the objectives of Directive 2014/104/EU and the principle of effectiveness of EU law.

\section{Directive 2014/104/EU}

Directive 2014/104/EU gives strong arguments that the claims for antitrust damages can be arbitrated. The Directive expressly appreciates alternative methods of dispute resolution and supports their use in claiming compensation for antitrust damages. Under Recital 5 the Directive 2014/104/EU states:

"Actions for damages are only one element of an effective system of private enforcement of infringements of competition law and are complemented by alternative avenues of redress, such as consensual dispute resolution and public enforcement decisions that give parties an incentive to provide compensation".

Under Recital 48 the Directive continues:

"Achieving a 'once-and-for-all' settlement for defendants is desirable in order to reduce uncertainty for infringers and injured parties. Therefore, infringers and injured parties should be encouraged to agree on compensating for the harm caused by a competition law infringement through consensual dispute resolution mechanisms, such as out-of-court settlements (including those where a judge can declare a settlement binding), arbitration, mediation or conciliation. Such consensual dispute resolution should cover as many injured parties and infringers as legally possible. The provisions in this Directive on consensual dispute resolution are therefore meant to facilitate the use of such mechanisms and increase their effectiveness".

The intention of the Commission was clearly to support the use of arbitration, mediation, and other consensual dispute resolution methods to deal with actions for antitrust damages. Consequently, the newly established framework for the private enforcement of EU competition law does not negate the use of arbitration to enforce competition law remedies.

Oddly, the wording of the Directive 2014/104/EU lacks clarity. Recital 48 lists all the methods of alternative dispute resolution in one line. This does not allow one to clearly establish the role of arbitration in handling claims for antitrust damages. For instance, it is difficult to see how arbitration could help lots of parties to raise their claims in the same arbitral proceeding. Arbitration is a creation of the contract, and is based on an arbitration agreement between the parties that have concluded it. The engagement of any other entities in an arbitral proceeding may bring serious difficulties (Hanotiau, 2016). Thus, antitrust class actions are not likely to be dealt with ease in arbitral proceedings. This leads me to question whether the use of arbitration to resolve antitrust damages is desirable, inasmuch as it ensures the effectiveness of EU law. 


\section{Principle of effectiveness of EU Law}

The principle of effectiveness has been used by the CJEU for a long time to ensure that the remedies existing in national law ensure the execution of rights derived from EU law. The definition of its content presents some difficulties since the CJEU has used it on multiple occasions with the aim of achieving various objectives.

It can be observed that the principle of effectiveness is used as an elimination rule, allowing one to disregard national provisions that make the enforcement of EU rights practically impossible or excessively difficult. This function is reflected in Article 4 of Directive 2014/104/EU:

"all national rules and procedures relating to the exercise of claims for damages are designed and applied in such a way that they do not render practically impossible or excessively difficult the exercise of the Union right to full compensation for harm caused by an infringement of competition law".

The principle of effectiveness is, however, also used to provide for a minimal content of the remedies that ensure the protection of EU law. In Manfredi, the CJ specified that a claim for antitrust damages shall encompass damnum emergens, lucrum cessans and the interests ${ }^{19}$. Such an understanding of the principle of effectiveness presupposes that sufficient remedies shall be available to provide for the effective protection of EU law. According to Reich, this allows for the creation of hybrid EU remedies, which combine the elements of national law with the changes required to ensure effective protection of EU rights (Reich, 2013, p. 309).

In light of this historic development, Lianos is right to state that the main function of the principle of effectiveness is to maximise the sufficient attainment of the ends pursued by the primary right by providing the 'adequate' content to the secondary right of claiming antitrust damages, and not to sculpt the essence of the primary right (Lianos, 2014, p. 8).

In order to verify whether the principle of effectiveness impedes the use of arbitration to enforce the claims for antitrust damages, it needs to be asked what the content of the claim for antitrust damages is (i) and whether its enforcement in arbitral proceedings sufficiently ensures the enforcement of EU provisions in competition law (ii).

\subsection{Content of the claim for antitrust damages}

The claim for antitrust damages was given a core content by the $\mathrm{CJ}$ in the Manfredi case:

19 CJ judgment of 13.06.2006, Case C-295/04 Manfredi, ECLI:EU:C:2006:461. 
"it follows from the principle of effectiveness and the right of any individual to seek compensation for loss caused by a contract or by conduct liable to restrict or distort competition that injured persons must be able to seek compensation not only for actual loss (damnum emergens) but also for loss of profit (lucrum cessans) plus interest" 20 .

The claim for antitrust damages has thus been defined in terms of substantive law. The CJ included minimal elements that the national laws of EU Member States must ensure when dealing with claims for compensation in the context of competition law.

The content of the claim for antitrust damages has been further developed by the Directive 2014/104/EU. The Directive includes some further elements of substantive law: it guarantees the right of full compensation, introduces joint and several liability of infringers, regulates the status of indirect purchasers ${ }^{21}$. It also contains some procedural rules concerning, for instance, the disclosure of evidence, effects of the decisions of competition authorities, limitation periods $^{22}$.

The traditional claim for compensation as regulated under national tort laws, together with the modifications ensured by the Directive 2014/104/EU, constitute the content of the claim for antitrust damages that adequately ensures the protection of EU law. It remains to be verified whether such a claim can be enforced in arbitral proceedings.

\subsection{Enforcement of the claims for antitrust damages in arbitral proceedings}

There is little doubt that arbitral proceedings apply the same laws and rights as national judges. Arbitrators apply substantive law that is relevant to the dispute ${ }^{23}$. This means that they are bound to apply national provisions transposing Directive 2014/104/EU in a given national legal order. Consequently, they enforce the same claim for antitrust damages as national judges of a relevant EU Member State.

The potential misapplication of the right to compensation in the context of competition law is not only a problem of a potential error of law, but it may also amount to a breach of public policy. EU competition rules are mandatory norms and the CJ in the Eco Swiss case stated that they belong to the rules

20 C-295/04 Manfredi, para. 100.

21 See respectively Article 3, 11, 14 of Directive 2014/104/EU.

${ }_{22}$ See respectively Article 5 to 8, 9, 10 of Directive 2014/104/EU.

23 This is apart from the possibility of parties to choose the adjudication according to the rules of ex aequo et bono or as amiable compositeur. See Lew, Mistelis and Kröll, 2003, paras 18-1-7, 18-86-92. 
of ordre public ${ }^{24}$. Consequently, EU competition law needs to be applied even if the adjudication is made on the basis of ex aequo et bono or non-EU law (Landolt, 2011). Furthermore, at the stage of recognition and enforcement of arbitral awards, national courts of EU Member States retain control of whether EU competition law has been addressed by arbitrators adequately (Geradin, 2016). Such competence guarantees that the claims for antitrust damages are sufficiently enforced by arbitrators.

It is thus puzzling why Advocate General Jääskinen states in the $C D C$ case ${ }^{25}$ that the execution of arbitration clauses concluded before the competition dispute has arisen does not guarantee the effectiveness of EU law. The problem, it seems to him, is the fact that the seat of arbitration may be outside the EU:

"Nevertheless, a clause conferring jurisdiction in accordance with Article 23 of the Brussels I Regulation may confer jurisdiction only on the courts of Member States of the European Union and by extension, under the Lugano Convention, on the courts of the Parties to that Convention, whereas an arbitration clause may provide that arbitration is to take place in any third State whatsoever. The likelihood of provisions of EU competition law not being applied, even by way of public policy rules, is much greater when jurisdiction is conferred on arbitrators or courts of States not bound by the Lugano Convention"26.

Such a conclusion demonstrates the AG's misconception of arbitration law. First, the seat of arbitration matters to a limited extent. Its influence is predominantly limited to the relations with local courts, conflict of laws rules and proceedings for the annulment of arbitral awards (Born, 2011). A seat that is outside the EU does not allow the arbitrators applying one of the EU laws to disregard EU competition law. Furthermore, the rules of public policy ensure that the application of EU competition law is of the utmost priority to every arbitrator, even one proceeding from outside the EU. Its disregard may lead to rendering a defective award and would be a breach of the arbitrator's obligation to render a valid and enforceable award. Such an award cannot be enforced or recognized in the EU (Geradin, 2016).

AG Jääskinen continues that his view does not rule out the possibility that victims of competition law infringements could not obtain full compensation in other forums. However, exercising such a right is likely to be more difficult:

"It is true that the application of jurisdiction or arbitration clauses is not in itself an obstacle to the effectiveness of Article 101 TFEU within the meaning of the

24 C-126/97 Eco Swiss, para. 39.

25 Opinion of Advocate General Jääskinen, delivered on 11.12.2014, Case C-352/13 CDC Hydrogen Peroxide, ECLI:EU:C:2014:2443.

26 Ibidem, para. 100. 
case-law cited (...) given that [the individuals] are not prevented from bringing actions before each of the appointed national or arbitration courts, even though, given the wide variety of clauses relied upon in this case, their application would certainly be likely to render such a course of action more difficult"27.

AG Jääskinen does not specify what the difficulties are that the parties may face when enforcing the claim for antitrust damages before arbitrators. It is, however, worth mentioning that the modifications introduced by Directive 2014/104/EU in the field of procedural laws are also indirectly applied in arbitral procedures. Arbitral procedure is a complex field and cannot be addressed in detail here. However, the flexibility of it allows for reaching similar solutions as those present in Directive 2014/104/EU.

For instance, most of the procedural rules provide arbitrators with a wide scope of power concerning the disclosure of evidence ${ }^{28}$. IBA Rules on the Taking of Evidence set a very detailed mechanism to deal with the requests for disclosure and the production of evidence. The arbitrators can order the disclosure of evidence. However, the parties' should request only a narrow and specific category of documents that they believe to exist; determine how such documents are relevant to the case; give reasons why they cannot obtain the evidence themselves, as well as why they believe the evidence to be in the possession of another party ${ }^{29}$. The arbitrators also enjoy a large degree of discretion in allowing for certain categories of evidence, and should refuse the documents protected by the Directive 2014/104/EU, such as leniency applications ${ }^{30}$. Even though, arbitrators cannot impose fines on those avoiding the delivery of evidence, they can attach adverse consequences to their arguments ${ }^{31}$, impose on them the costs and legal fees (Salomon and Friedrich, 2013) or ask local courts for the imposition of fines pursuant to national provisions implementing Directive 2014/104/EU ${ }^{32}$. This demonstrates that procedural solutions present in Directive 2014/104/EU are also likely to be applied in arbitral proceedings.

27 AG Jääskinen's opinion, para. 143.

28 See, e.g. Article 25(1) and 25(5) of ICC Arbitration Rules; Article 27(3) of UNCITRAL Arbitration Rules; Article 27(3) of LCIA Arbitration Rules.

29 Article 3 of IBA Rules on the Taking of Evidence in International Arbitration.

30 Article 9(f) of the IBA Rules on the Taking of Evidence in International Arbitration guarantee that arbitrators shall excluded the evidence or production of evidence on "grounds of special political or institutional sensitivity."

31 See, e.g. Article 9(5) and 9(6) of IBA Rules on Taking of Evidence in International Arbitration, Article 25(c) of UNCITRAL Model Law. See also, Driessen-Reilly, 2015, p. 578.

32 Article 27 UNCITRAL Model Law, Article 1693-1694 of Belgian Arbitration Law, Sections 33-34 of English Arbitration Act, Article 1460-1461 of French New Code of Civil Procedure (NCPC), Sections 1042, 1049-1050 of German Code of Civil Procedure (ZPO), Articles 1036, 1039-1044 of Dutch Code of Civil Procedure (CCP). 
AG Jääskinen's opinion in the $C D C$ case was not followed by the $C J$, which did not express its views on arbitration agreements ${ }^{33}$. This additionally supports the fact that arbitrating claims for antitrust damages does not per se impede the effectiveness of EU law ${ }^{34}$. If the CJ was of the view that the effectiveness of EU competition law is endangered by the application of arbitration clauses, it had a perfect opportunity to express it.

\subsection{Conclusions}

Claims for antitrust damages are enforced by arbitrators and by national judges in a similar way. There is little risk that the substantive and procedural content of a claim for antitrust damage will not be respected and enforced in arbitral proceedings. Additionally, the principle of public policy poses a further safeguard, in that every arbitral proceeding will enforce the rights derived from EU competition law provisions of the Treaties. Finally, Directive 2014/104/EU expressly promotes handling the actions for damages by means of alternative methods of dispute resolution ${ }^{35}$. This demonstrates the general compatibility of arbitrating claims for antitrust damages with the principle of effectiveness in EU competition law.

\section{Interpreting the scope of arbitration agreements}

After having observed that the actions for antitrust damages are arbitrable and their handling by arbitrators is in line with the principle of effectiveness, the ultimate question remains whether actions for antitrust damages are within the scope of an arbitration agreement.

This problem is likely to arise frequently in practice. Parties that stay in direct contractual relations may conclude agreements containing arbitration clauses. It is likely that they will use model arbitration clauses that cover all the disputes arising out of or in connection with the contract. ${ }^{36}$ Should one of the parties commit a breach of EU competition law and damage its direct contractor, it will be asked whether the claims for antitrust damages fall within the scope of such an arbitration agreement.

33 C-352/13 CDC Hydrogen Peroxide, para. 58.

34 The term per se is used to express the general suitability of arbitration as a means to deal with the claims for antitrust damages.

35 See section IV. of this paper.

36 Every arbitration institution provides for a recommended model arbitration clause; herewith the example of the ICC Standard Arbitration Clause. 


\section{Impact of the $C D C$ case}

In the $C D C$ case the $C J$ dealt mainly with the question of whether the execution of different arbitration and jurisdiction clauses was in line with the principle of effectiveness in EU law. On this occasion, the CJ expressed yet some interesting opinions on the interpretation of the scope of the clauses in question.

\subsection{Opinion of Advocate General Jääskinen}

As shown in the previous section, AG Jääskinen's opinion features a certain distrust of using arbitral proceeding to deal with the actions for antitrust damages. He does not preclude that arbitration agreements in themselves upset the principle of the full effectiveness of EU competition law. Nevertheless, he requires that they are agreed with the awareness of a cartel agreement in order to cover the claims for antitrust damages.

"In consequence, I consider that Article 101 TFEU must be interpreted as meaning that, in the context of an action for compensation for damage caused by an agreement declared to be contrary to that article, the implementation of jurisdiction and/or arbitration clauses does not in itself compromise the principle of the full effectiveness of the prohibition of agreements, decisions and concerted practices. In so far as a clause of one or other of those categories could be declared applicable, pursuant to the law of a Member State, in a dispute concerning liability in matters of tort, delict or quasi-delict that might follow from such an agreement, that principle, in my view, precludes jurisdiction over that dispute being attributed under a clause of a contract whose content had been agreed when the party against whom that clause is relied on was unaware of the cartel agreement in question and of its unlawful nature, and could not, therefore, have foreseen that the clause could apply to the damages sought on that basis" 37 .

The reason why AG requests that arbitration and some jurisdiction agreements be concluded after the dispute has arisen is the fact that the parties could not have foreseen the violation of EU competition law and the damages arising on such a basis. Along the same lines, AG Jääskinen believes that arbitration and jurisdiction clauses cannot encompass tort claims since they are not sufficiently connected with the contract concluded by the parties:

"In my opinion, the rights relied upon in this case derive (...) from the tort consisting of the cartel agreement arranged and put in hand, covertly, by the defendants in the main proceedings. The issue in the case in the main proceedings is the pecuniary

37 AG Jääskinen's opinion, para. 132. 
consequences of that fraudulent conduct, which is inherently different from the supply contracts invoked" 38 .

Such reasoning clearly contradict the principle that individuals have autonomy in exercising their disposable rights. This autonomy also encompasses the determination of the forum to resolve disputes relating to such rights and shall be respected (Nygh, 1999). The fact that claims may have their basis in tort law does not preclude the parties from subjecting future disputes relating to them to the adjudication of arbitrators. It is only the interpretation of an arbitration clause that allows stating whether the parties had a will to cover a given dispute within the scope of arbitration agreement (Mistelis \& Kröll, 2003). The reconstruction of the parties' intentions is subjected to the rules on the interpretation of will expressions under applicable national laws (Ereciński, Weitz, 2008, para. III.3.5). AG Jääskinen does not refer to any of such laws. As a result, the abstract statement that it is unlikely that arbitration agreements cover tort claims is groundless.

\subsection{Judgment of the Court}

The $C D C$ judgment covers only jurisdiction clauses falling under the scope of Regulation 44/2001. The Court expressed that it did not have sufficient information to decide whether the execution of arbitration clauses was consistent with the effectiveness of EU competition law ${ }^{39}$.

With respect to jurisdiction clauses covered by Article 23 of Regulation $444 / 2001$, the Court stated that the effectiveness of EU competition law cannot be called into question by the execution of jurisdiction clauses related to actions for antitrust damages ${ }^{40}$. However, the central question was whether the investigated jurisdiction clauses covered actions for antitrust damages. Following its case law relating to Regulation 44/2001, the CJ observed that:

“(...) a jurisdiction clause can concern only disputes which have arisen or which may arise in connection with a particular legal relationship, which limits the scope of an agreement conferring jurisdiction solely to disputes which arise from the legal relationship in connection with which the agreement was entered into. The purpose of that requirement is to avoid a party being taken by surprise by the assignment of jurisdiction to a given forum as regards all disputes which may arise out of its relationship with the other party to the contract and stem from a relationship other than that in connection with which the agreement conferring jurisdiction was made" 41 .

\footnotetext{
38 Ibidem, para. 130.

39 C-352/13 CDC Hydrogen Peroxide, para. 58.

40 Ibidem, paras 62-63.

${ }^{41}$ Ibidem, para. 68.
} 
According to the $\mathrm{CJ}$, the execution of jurisdiction clauses as described in Article 23 of Regulation 44/2001, does not impede the effectiveness of EU law. However, abstract jurisdiction clauses are not likely to encompass actions for antitrust damages.

\subsection{Reactions to the $C D C$ case}

The silence of the CJ with respect to arbitration clauses only enhanced doubts about how to treat them, and whether to apply the reasoning of the CJ by analogy also to arbitration clauses.

The Amsterdam Court of Appeal was of the opinion that the reasoning of the $\mathrm{CJ}$ with respect to jurisdiction clauses should be extended to the assessment of arbitration clauses. In dealing with the CDC's actions for antitrust damages in the Netherlands, it observed that:

“(...) there are no reasons to rule differently with respect to the arbitration clauses.

With regard to these clauses, it is necessary to conclude that the undertaking harmed by the competition law did not agree on the arbitration clause that covers the claims resulting from infringements of competition law"42.

The equal treatment of arbitration and jurisdiction clauses has also found support in academic writing. For instance, Ch. Harler is of the opinion that model arbitration clauses typically do not cover disputes over cartel damages claims. With regard to jurisdiction clauses, the ECJ holds that in the absence of an explicit inclusion, standard jurisdiction clauses do not reach cartel damages claims. There is no indication that the CJEU would not also apply this interpretation to arbitration clauses (Harler, 2015, p. 121-123).

Such reasoning cannot be accepted. The reference to the $C D C$ judgment is mistaken since the Court left arbitration clauses beyond the scope of its assessment. Furthermore, contrary to what is claimed by the Amsterdam Court of Appeal and Harler, there are strong reasons for not extending the CJ's reasoning to the interpretation of arbitration agreements.

Regulation 44/2001 is an instrument of private international law, whose objective is to determine the jurisdiction of disputes that have an international element. Article 23 of the Regulation provides for a definition of a jurisdiction agreement, which produces effects under the Regulation. According to Article 23 of Regulation 44/2001, jurisdiction agreements cover "any disputes which have arisen or which may arise in connection with a particular legal

42 Gerichshof Amsterdam, 21.07.2015, CDC v. Akzo Nobel, 200.156.295/01, para. 2.16. Similarly, arbitration clauses were not executed in a follow-on claim against elevator and escalator manufacturers adjudicated by Utrecht District Court. See Utrecht District Court, 27.11.2013, East West Debt v United Technologies Corporation c.s. 
relationship". The role of CJEU is to interpret this provision, as was done so in the $C D C$ case.

On the contrary, under Article 1(2)(d) of Regulation 44/2001, arbitration is outside the scope of the Regulation. The aim of arbitration is to provide for a private forum of adjudication when parties are willing to derogate from the national court jurisdiction. The transfer of jurisdiction is made on the basis of an arbitration agreement, which is determined by the parties. It has no pre-defined scope and it expresses the will of specific parties to subject specific disputes to the adjudication of arbitrators (Lew, Mistelis \& Kröll, 2003, paras 6-1-2). As a result, the scope of an arbitration agreement needs to be interpreted in light of national provisions on the interpretation of expressions of will, and with reference to the national case law on the interpretation of arbitral agreements. The CJ expressed that it did not have sufficient information to conduct such an analysis, and limited its assessment only to the problems arising in the field of private international law. Such limitation of the $C D C$ judgment shall be respected.

It can be raised that it is the principle of effectiveness of EU law that requires the application of the $C D C$ judgment by analogy to the assessment of arbitration clauses. The previous part has demonstrated however that the use of arbitration to deal with the claims antitrust damages does not per se impede the effectiveness of EU law. If the CJ was of the view that the effectiveness of EU competition law is endangered by the application of arbitration clauses, it would not hesitate to express it. The suitability of arbitration as a means to deal with claims for antitrust damages is a general problem and could have been addressed by the $\mathrm{CJ}$ without the need to refer specifically to the given arbitration clause.

Consequently, if the national courts feel the risk that the principle of effectiveness is endangered by the execution of a given arbitration clause they shall not apply the $C D C$ judgment by analogy, but rather analyse the principle of effectiveness in concreto, namely by assessing the effects of execution of the specific arbitration clause with its specific characteristics. Such an assessment is separate to the question of the scope of arbitration agreement and shall be undertaken only if the arbitration clause covers claims for antitrust damages.

\section{Polish experience in interpreting arbitration clauses}

The scope of arbitration agreements needs to be determined with reference to the parties' expressions of will interpreted according to the applicable national laws. There can be situations when parties expressly agree on how to treat the actions for antitrust damages. However, it is more common for 
parties to conclude arbitration clauses that refer vaguely to disputes that could arise between them as it is not known to them, which specific disputes will occur. The interpretation of such clauses is crucial to identify the relevant forum for specific disputes.

In order to show how arbitration clauses may be interpreted in the event of commenced claims for antitrust damages, the paper draws on the jurisprudence of Polish courts concerning the attempts to arbitrate private disputes resulting from infringements of Polish Law on Unfair Competition with respect to slotting fees ${ }^{43}$.

The choice of case law from the field of unfair competition results from the fact that it has a few shared characteristics with competition law ${ }^{44}$. Firstly, the problem of slotting fees is of importance for both the competition and unfair competition law. Under Polish law, they are considered as an act of unfair competition, yet at the same time they create barriers for market entry, which can be perceived as anti-competitive under competition law (Wright, 2006). Second, civil consequences that are triggered by acts of unfair competition are, to a large extent, similar to the ones that result from violations of EU competition law. Both fields provide as remedies claims for the recovery of unjust enrichment and compensation ${ }^{45}$. The claims arise from the others' misconduct and aim at restoring a situation that existed before the breach of law, by compensating the victim for sustained losses (Fézer, 2013, pp. p. 7-11). In both areas, such claims have a distinctive and independent character from other claims that may exist between the parties, in particular contractual claims. As a result, the arguments for and against the inclusion of actions for damages within the scope of arbitration agreements are likely to be similar in both fields.

\subsection{Legal framework}

Slotting fees are the charges imposed by supermarket distributors on their suppliers for having their products placed on supermarket shelves. Such fees may create a barrier, stopping small businesses that do not have enough financial resources to create their own distribution systems and compete with

43 Act of 16 April 1993 on Combating Unfair Competition (Journal of Laws 2003 No 153, item 1503).

${ }^{44}$ Even thought, the aims of EU competition law an law on unfair competition are not the same as expressed under Recital 9 of Regulation 1/2003, the reference to such case law may be helpful for the reasons specified.

45 With respect to competition law see C-295/04 Manfredi, para. 100 and CJ judgment of 16.12.2008, Case C-47/07 P Masdar (UK) Ltd v Commission of the European Communities, ECLI:EU:C:2008:726, paras 44-47. With respect to Polish Law on Combating Unfair Competition see Article 18 of the Law. 
large companies, from entering the market. Under Polish law, slotting fees are considered an act of unfair competition and are declared illegal:

"It is an act of unfair competition to restrict access to the market for other undertakings, in particular by (...) requesting charges other than the trade margin for receipting a good for the purpose of sale" 46 .

The violation of the interests of fellow entrepreneurs or clients by the acts of unfair competition triggers civil consequences. According to Article 18(1) of the Law on Combating Unfair Competition:

"In the event of an act of unfair competition, an entrepreneur, whose interests have been threatened or damaged may request:

1) abandonment of illicit activities;

2) removal of the effects of illicit activities;

3) single or multiple statement of an appropriate content and form;

4) compensation for damages according to general rules;

5) recovery of unjust enrichment according to general rules;

6) awarding an adequate sum for a specific social purpose related to the promotion of Polish culture or protection of national heritage - if an act of unfair competition was committed culpably".

Against this framework, it is plausible that an act of unfair competition would occur when the infringer and the person damaged stay in contractual relations. For instance, the parties may have concluded a supply or distribution agreement. Such agreements may also entail an arbitration clause. The question arises whether an arbitration agreement also covers, apart from contractual claims, the claims under Article 18 of the Law on Combating Unfair Competition, in particular claims for damages and unjust enrichment. This problem was subjected multiple times to the analysis of the Polish Supreme Court.

\subsection{Jurisprudence Relating to Polish Law on Unfair Competition}

\subsubsection{Judgment of the Supreme Court of 2 December 2009}

The present case ${ }^{47}$ concerns a dispute between a supplier of construction products and a company operating an OBI store, the largest "do-it-yourself" retailer in Europe. The supplier claimed the recovery of unjust enrichment under Article 18(1)(5) of the Law on Combating Unfair Competition as a result of being forced to pay slotting fees.

46 Article 15(4) of Polish Law on Combating Unfair Competition. Specifically regarding slotting fees: judgement of the Supreme Court of 26.01.2006, II CK 378/05.

47 Judgement of the Supreme Court of 2.12.2009, I CSK 120/09. 
The dispute was, however, mainly focused on the problem of jurisdiction, in which the claims for recovery of unjust enrichment are enforced. The source of controversy was the fact that the parties concluded a series of agreements with arbitration clauses. The agreement on commercial cooperation, agreement on the provision of services and the agreement on bonuses resulting from increased volumes of sale included the following arbitration clause:

"The Parties will endeavor to resolve consensually any disputes resulting from the agreement or connected with it. Should a dispute be impossible to resolve within a month, its resolution shall be subjected to the adjudication of the Court of Arbitration at the Polish Chamber of Commerce in Warsaw, and shall be governed by its Rules applicable on the day of commencing the proceeding" 48 .

The question was whether the claim for unjustified enrichment under Article 18(1)(5) of the Law on Combating Unfair Competition was within the scope of the arbitration agreement. The Supreme Court stated that such a claim had a distinctive character and it was independent from the contractual and tort liability of the infringer. The Supreme Court concluded that, even though such a claim was arbitrable, it was not covered by the arbitration agreement. According to the judges:

"The reason for such a conclusion was that the agreements concluded between the parties were aimed at regulating the cooperation of the parties with respect to the sale of products. Slotting fees can neither be considered as the execution of the agreements, nor as being in connection with them, but they were charged only on a mere occasion of execution of the agreements. As a result, the claim in question does not have a contractual character and is not in connection with the agreements. To the contrary it concerns the act of unfair competition that was undertaken by one of the parties" 49 .

Furthermore, the Court expressed that it is unlikely that the parties had foreseen the occurrence of acts of unfair competition, and could not have intended to cover them by the arbitration agreement. In conclusion, the Court rejected the claim that lower instances lacked jurisdiction to deal with the claims under Article 18(1)(5) of the Law on Unfair Competition ${ }^{50}$.

\subsubsection{Judgement of the Supreme Court of 5 February 2009}

The Supreme Court endorsed different view regarding the interpretation of arbitration agreements in another case relating to slotting fees ${ }^{51}$. The

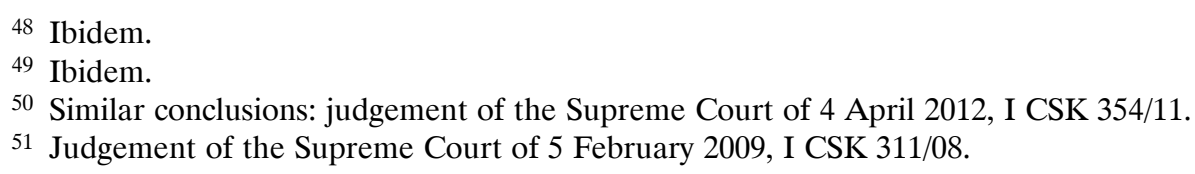


dispute occurred between parties that concluded a framework agreement for commercial cooperation. It included a two-tier arbitration clause, summarized by the Court as follows:

"With respect to the disputes relating to the interpretation of the framework agreement for commercial cooperation, the general terms and conditions for the purchase and delivery or the execution of the orders the parties will follow a two-step procedure of dispute resolution: a) consensual resolution by means of negotiation conducted by two authorized representatives of the Parties; b) 30 days after the initiation of the negotiation each of the Parties is entitled to commence an action before the Court of Arbitration at the Polish Chamber of Commerce in Warsaw"52.

The Supreme Court was of the opinion that slotting fees were charged by means of marketing and advertising charges, and that the dispute related thereby to the interpretation of the agreements concluded by the Parties. Such a conclusion was not influenced by the fact that the Court qualified the imposition of such charges as an act of unfair competition. The Court also referred to the following:

“(...) according to the views represented in legal literature, submitting disputes resulting from contractual relations to an arbitral tribunal means that the arbitral tribunal has the power to rule on claims for the execution of the contract, claims caused by non-performance or undue performance of the contract, claims for unjust enrichment resulting from the invalidity or termination of the contract and tort claims, which are caused by an event that is at the same time a non-performance or an undue performance of the contract" 53 .

After having stated that the claims under Article 18 of the Law on Combating Unfair Competition are in sufficient connection with the agreement, the Court sided with the party claiming that the action for recovery of unjust enrichment falls within the scope of the arbitration agreement and shall be resolved by the arbitrators.

\subsubsection{Judgement of the Supreme Court of 24 October 2012}

The Supreme Court dealt once again with the interpretation of arbitration clauses regarding claims for unjust enrichment resulting from slotting fees on 24 October $2012^{54}$. Since disputing parties relied on previous case law in their submissions, the Court conducted a profound analysis of the nature of claims resulting from violations of the Law on Combating Unfair Competition.

\footnotetext{
52 Ibidem.

53 Ibidem.

54 Judgment of the Supreme Court of 24 October 2012, I CSK 354/11.
} 
In the present case, an arbitration clause was included in both a sales contract and a contract for the provision of promotional services. It was worded as follows:

"The arbitration tribunal is exclusively competent to resolve all the disputes arising from the legal relationship between the parties, regardless of the dates of their occurrence, including, in particular, disputes relating to claims for the execution of the sales contract and the contract for provision of promotional services, claims arising in the event of a non-performance or undue performance of the contracts, claims for the recovery of an unjustified provision of services in the event of the invalidity of the contracts or their parts or withdrawal from the contracts, as well as any tortious claims, if they arise from an event related to the execution of the contracts or which are simultaneously a non-performance or undue performance of the contracts" 55 .

The claimant put forward the notion that the courts had the jurisdiction to deal with the dispute. According to him, the claim for unjust enrichment under Article 18(1)(5) of the Law on Combating Unfair Competition has a distinctive character and is independent from the contractual and tortious liability of the infringer. As a result, it cannot fall under the arbitration clause included in the contracts.

Although the Supreme Court agreed with this statement, it stated, however, that it is not the nature of the claim that decides on its qualification within the scope of arbitration claims. Rather, it is the content of the arbitration agreement that is essential.

Consequently, the Court analysed whether the claim for unjustified infringement under Article 18(1)(5) of the Law on Combating Unfair Competition falls within one of the classes of claims listed in the arbitration clause. To that end, the Court wondered whether the imposition of unlawful charges was made by the sales contract itself or whether the charges were imposed next to the agreement for sales. Ultimately, the Court left these questions open since the arbitration clause covered many types of claims ${ }^{56}$.

\subsection{Critics}

The review of the Supreme Court's case law allows one to state that there is no uniform tendency concerning the interpretation of arbitration clauses in the field of law for unfair competition in Poland ${ }^{57}$.

55 Ibidem.

56 Ibidem.

57 See also the case law of appeal courts: judgment of the Court of Appeals in Poznań of 10.01.2013, I ACz 2239/12; judgment of the Court of Appeals in Poznań of 11.04.2013, I ACz $592 / 13$. 
On the one hand, there is a trend to interpret arbitration clauses widely, as expressed by the Supreme Court in the judgement of 5 February 2009. If an arbitration clause stipulates that it covers the disputes relating to a contract, such clauses are meant to cover: claims for the execution of a contract (i), claims caused by its non-performance or undue performance (ii), claims for unjust enrichment resulting from the invalidity or termination of a contract (iii) and tort claims, which are caused by an event that means also non-performance or undue performance of a contract (iv). The claims resulting from the violation of the Law on Combating Unfair Competition are likely to be encompassed by them.

On the other hand, the judgement of 2 December 2009 indicates that the arbitration clauses are required to be specific, and describe in detail the disputes that are encompassed thereby. Since the claims resulting from the breach of Law on Combating Unfair Competition have a distinctive character and are enforced independently from other claims, they shall be specifically referred to by an arbitration clause.

Even though Polish courts do not give an ultimate answer as to which of these approaches shall be chosen, they have commenced an interesting discussion about the relation between the contract existing between the parties and claims resulting from the violation of the Law on Combating Unfair Competition.

The courts state that the sole nature of the claim cannot decide whether the parties aimed at covering it by the arbitration agreement. Instead of analysing the nature of the claim, the judges put more emphasis on the connection, which is between the misconduct and the contract. The judges ask multiple times whether the infringement was made by the contract itself, next to the contract, or on a mere occasion of executing the contract. Such classification seems to be vital for deciding whether there is a sufficient nexus of claims under the Act of Combating Unfair Competition with the arbitration clause regulating usually legal relations covered by the contract.

This discussion is essential also from the standpoint of actions for antitrust damages. In order to assess whether the claims resulting from the violation of EU competition law are covered by an arbitration agreement relating to the contractual relations between the parties, the key may be to ask whether the claims for antitrust damages have a sufficient connection with the contract. 


\section{Addressing Misconceptions Concerning the Arbitration of Antitrust Damages}

Both the Polish case law related to slotting fees and the analysis of the $C D C$ case by the EU Courts reveal some misconceptions that concern the arbitration of claims for antitrust damages. One of them was the so-called distinct character of the claims resulting from the violation of EU competition law and Polish Law on Combating Unfair Competition, which makes the claims difficult to foresee and thus to include in the scope of an arbitration agreement. Another doubt was the non-contractual origins of such claims, which make them unlikely to be covered by arbitration agreements related to the contract. This section aims at addressing these problems.

\section{No awareness of future violation}

One of the arguments raised by AG Jääskinen and the Polish Supreme Court on 2 December 2009 was that the investigated claim could not be covered by an arbitration agreement since the parties to the agreement were unaware of the breach of law giving rise to the claim in the moment of concluding it.

Such an argument seems to be dubious. Arbitration agreements concluded before any dispute has arisen always involve some element of the parties' unawareness of future conflicts. It is thus difficult to request from the parties an awareness of any future events giving rise to specific claims (Wiśniewski, 2011). For instance, an arbitration clause that speaks of contractual disputes arising out of the contract shall cover disputes relating to the fact that a purchased product is different from the one described in the agreement, as well as disputes concerning a sudden termination of the contract. This is regardless of the parties' awareness of such problems in the moment of concluding the arbitration agreement.

Even though some claims may be believed to have a distinctive character from other claims stipulated by an arbitration clause, it shall not exclude them automatically from the scope of the arbitration agreement. This problem needs to be decided in reference to the will of parties to the arbitration agreement. In the case of difficulties of reconstructing the actual intent of the parties, most of jurisdictions support the approach of interpreting arbitration clauses in favour of arbitration ${ }^{58}$. As expressed by Lord Hoffman:

58 England \& Wales, see Herbst, 2012; United States, see Celik, 2014; Austria see Welser \& Moltioris, 2012; Germany, see Koller, 2012, para. 3.259. For a comparative overview see Poudret and Besson, 2007, p. 304-326, Lew, Mistelis and Kröll, 2003, paras 7-61-62. 
"In my opinion the construction of an arbitration clause should start from the assumption that the parties, as rational businessmen, are likely to have intended any dispute arising out of the relationship into which they have entered or purported to enter to be decided by the same tribunal. The clause should be construed in accordance with this presumption unless the language makes it clear that certain questions were intended to be excluded from the arbitrator's jurisdiction" 59 .

If an interpretation in favour of arbitration is a dominant in the given jurisdiction, it shall also be applied when deciding about the claims for antitrust damages. The unawareness of the parties of a future breach of antitrust law shall not justify departing from the principle of an arbitrationfriendly interpretation of arbitration agreements.

\section{Tort Origin of the Claim}

Another argument against the inclusion of actions for antitrust damages within the scope of an arbitration agreement is that tort claims are not related to the contract containing an arbitration clause. As described by the Polish Supreme Court on 2 December 2009, the violation can be believed to be not realised by the contract but to exist merely next to it. This classification is vital when the arbitration clause speaks only about contractual claims, or in a certain way limits the catalogue of tort claims to the ones related only to the contract.

The problem of whether non-contractual claims fall within the scope of arbitration agreements when their wording is unclear is decided under national arbitration laws and case law (Sadowski and Wętrys, 2014, p. 6-8). As a solution, some countries propose a distinction between the wording of "disputes arising out of the contract" and "disputes arising under the contract", so to delimit whether tort claims fall within the scope of arbitration agreements (e.g. United States; see Celik, 2014). However, in many other countries such a distinction has been abandoned in favour of including tort claims in the scope of arbitration agreements (e.g. England \& Wales, see Herbst, 2012; Austria and Switzerland, see Sadowski and Wętrys, 2014, p. 12-16). It is supported by the view that most frequently parties prefer to subject all the disputes between them to a single forum (one-stop-adjudication) (Sadowski and Wętrys, 2014, p. 11; Landolt, 2011, para. 12-105-107).

The problem of whether to follow the principle of one-stop-adjudication with respect to claims for antitrust damages is controversial (for the inclusion - see e.g. Basedow, 2007; against the inclusion - see e.g. Nazzini, 2008).

${ }^{59}$ Lord Hoffman in Fiona Trust \& Holding Corp. v. Privalov, [2008] 1 Lloyd's Rep. 254 (H.L.), para. 13. 
However, it shall not be doubted that the infringement of competition law has significant effects on the agreement concluded by the parties. For instance, cartels lead frequently to an overcharged price, which is an essential part of a contract.

In some instances, the entire decision to conclude an agreement can be influenced by the violation of competition law. Take bid rigging as an example. If the collusion between the bidders had not occurred, the organizer of the tender would not have concluded the agreement with a given bidder and would have chosen another contractor. As a result, it cannot be denied that competition law infringements are linked with the contract. It is thus not excluded that the violation of the competition law is made by the contract itself, as is expressed in the judgment of the Polish Supreme Court of 24 October 2012.

The question of whether the violation of competition law is made by the contract, next to the contract or on a mere occasion of its execution will always depend on the circumstances of the case. In situations in which the contract already materializes the infringement, it may be difficult to separate antitrust violation from a commercial contract between an infringer and a victim of antitrust violation. Under such circumstances it shall not be questioned that the claims resulting from competition law have a sufficient connection to the arbitration agreement related to the contract. Such a close nexus calls for dealing with both contractual claims and the claims for antitrust damages in one forum.

\section{Conclusions}

The question of whether arbitration agreements governing a general commercial relationship between the parties also cover the actions for antitrust damages cannot be answered in the abstract. There is always a given arbitration agreement and the context in which it has been concluded is of the utmost importance. The role of national law is to give guidelines for the interpretation of such agreements.

The CJEU has not given much guidance on how to treat arbitration agreements in the event of compensation claims for antitrust damages. Polish case law in the field of unfair competition law also does not provide for a coherent trend in interpreting arbitration clauses. Nonetheless, the courts raise many vital questions for dealing with the arbitration of claims of antitrust damages. This article aimed to analyse some of them, such as: the meaning of the parties' awareness of competition law concern in the moment 
of concluding an arbitration agreement; the impact of the tort origin of actions of antitrust damages or the need for a sufficient nexus between the violation of competition law and the contract to which the arbitration clause relates.

I believe that in principle there is nothing preventing the arbitration of antitrust damages. They are arbitrable in principle and the efficiency of EU competition law is not endangered. I propose an adoption of an arbitrationfriendly interpretation of the scope of arbitration clauses because in many situations the infringements of competition law will have significant repercussions on the contractual relationship between the parties. Under such circumstances, the actions for antitrust damages shall be dealt together in the same forum with the claims resulting from contractual violations.

\section{Literature}

Bagdziński, T. (2015). Arbitraż a prawo konkurencji - głos w dyskusji (artykuł polemiczny). internetowy Kwartalnik Antymonopolowy i Regulacyjny 4(4), 69-74.

Basedow, J. (2007). Jurisdiction and Choice of Law in the Private Enforcement of EC Competition Law. In J. Basedow (ed.). Private Enforcement of EC Competition Law, (pp. 229-257). Alphenaanden Rijn, Netherlands: Kluwer Law International.

Born, G.B. (2001). International Commercial Arbitration: Commentary and Materials. The Hague,Tthe Netherlands: Transnational Publishers, Kluwer Law International.

Boskowitz, K. (2009). Chapter 3: Optimal Sanctions and their Limitations. In Lianos I. \& Kokkoris I. (Eds.). The Reform of EC Competition Law: New Challenges, (pp. 95-119). Alphen aan den Rijn, The Netherlands: Kluwer Law International.

Celik, D.D. (2014). Interpretation and Enforcement of Arbitration Agreements under English and U.S. Law. Revue d'arbitrage et de médiation, 4(1), 19-43.

Driessen-Reilly, M. (2015). Private damages in EU competition law and arbitration: a changing landscape. Arbitration International 31(4), 567-587, doi: 10.1093/arbint/ aiv007

Ereciński, T. \& Weitz, K. (2008). Sąd arbitrażowy. Warszawa, Poland: LexisNexis.

European Commission, (2016). Press Release of 19 July 2016, Antitrust: Commission fines truck producers $€ 2.93$ billion for participating in a cartel. Retrieved from http://europa. eu/rapid/press-release_IP-16-2582_en.htm (19.05.2017).

Fézer, T. (2013). Comparative Tort Lâw. Retrieved from http://szaknyelvtudas.unideb.hu/ images/tananyagok/Comparative_Tort_Law_-_Dr_Fezer_Tamas.pdf (19.05.2017).

Geradin, D. (2016). Public Policy and Breach of Competition Law in International Arbitration: A Competition Law Practitioner's Viewpoint. TILEC Discussion Paper No. 2016-029, 1-31, https://doi.org/10.2139/ssrn.2786370

Geradin, D. and Villano, E. (2016). Arbitrability of EU Competition law-based claims: Where do we stand after the CDC Hydrogen Peroxide case? TILEC Discussion Paper, DP 2016-033, 1-25, https://doi.org/10.2139/ssrn.2851112

Hanotiau, B. (2016). Complex Arbitrations: Multiparty, Multicontract, Multi-Issue and Class Actions. Alphen aan den Rijn, The Netherlands: Kluwer Law International. 
Harler, Ch. (2015). The ECJ's CDC-Judgment on Jurisdiction in Cartel Damages Cases: Repercussions for International Arbitration. Europäisches Wirtschafts- und Steurrecht, 3, 121-123.

Koller, Ch. (2012). Die Schiedsvereinbarung. In Ch. Liebscher, P. Oberhammer and W.Ch. Rechberger (Eds.) (2011). Schiedsverfahrensrecht. Wien, Austria: Springer.

Komninos, A.P. (2011). Chapter 12: Arbitration and EU Competition Law in the Post Modernization Era. In G. Blanke and Ph. Landolt (Eds.), EU and US Antitrust Arbitration: A Handbook for Practitioners (pp. 433-487). Alphen aan den Rijn, The Netherlands: Kluwer Law International.

Kuijpers, M., Tuinenga, S., Wisking, S., Dietzel, K., Campbell, S. and Fritzsche, A. (2015) Actions for Damages in the Netherlands, the United Kingdom, and Germany. Journal of European Competition Law \& Practice, 6(2), 1-14. doi: 10.1093/jeclap/lpu125

Landolt, Ph. (2011). Chapter 2 Arbitration Clauses and Competition. In G. Blanke $\&$ Ph. Landolt (Eds.), EU and US Antitrust Arbitration: A Handbook for Practitioners (pp. 68-89). Alphen aan den Rijn, The Netherlands: Kluwer Law International.

Landolt, Ph. (2011). Chapter 15: The Application of EU Competition Law in International Arbitration in Switzerland. In G. Blanke and Ph. Landolt (Eds.), EU and US Antitrust Arbitration: A Handbook for Practitioners (pp. 545-565). Alphen aan den Rijn, The Netherlands: Kluwer Law International.

Lianos, I. (2014). The Principle of Effectiveness, Competition Law Remedies and the Limits of Adjudication. CLES Research Paper Series 6/2014, 1-30.

Lew, J.D.M., Mistelis, L.A. and Kröll S. (2003). Comparative International Commercial Arbitration. The Hague, The Netherlands: Kluwer Law International.

Mourre, A. (2011). Chapter 1: Arbitrability of Antitrust Law from the European and US Perspectives. In G. Blanke and Ph. Landolt (Eds.), EU and US Antitrust Arbitration: A Handbook for Practitioners (pp. 3-67). Alphen aan den Rijn, The Netherlands: Kluwer Law International.

Nazzini, R. (2008). A Principled Approach to Arbitration of Competition Law Disputes: Competition Authorities as Amici Curiae and the Status of Their Decisions in Arbitral Proceedings. European Business Law Review, 19(1), 89-114.

Nowaczyk, P. and Syp, Sz. (2013). Arbitraż a prawo konkurencji - wybrane zagadnienia teoretyczne i praktyczne. internetowy Kwartalnik Antymonopolowy i Regulacyjny 5(2), 81-89.

Nygh, P. (1999). Autonomy in International Contracts. New York, United States: Oxford University Press.

OECD. (2010). Arbitration and Competition. Paris, France.

Poudret, J.-F. and Besson, S. (2007). Comparative Law of International Arbitration. London, UK: Sweet \& Maxwell.

Reich, N. (2013). The Principle of Effectiveness and EU Private Law. In U. Bernitz, X. Groussot, F. Schulyok (Eds.), General Principles of EU Law and European Private Law, (pp. 301-326). Alphen aan den Rijn, The Netherlands: Kluwer Law International.

Ritter, L. and Braun, W.D. (2005). European Competition Law: A Practitioner's Guide. Hague, The Netherlands: Kluwer Law International.

Sadowski, W. and Wętrys, E. (2014). The arbitration clause in an underlying contract and non-contractual claims arising in connection with such contract. Arbitration e-Review, 3-4(18-19), 6-41. 
Salomon, C.T. and Friedrich, S. (2013). Obtaining and Submitting Evidence in International Arbitration in the United State. The American Review of International Arbitration 24(4), 549-590.

Syp, Sz. (2015). Arbitraż a prawo konkurencji - w odpowiedzi doktorowi Tomaszowi Bagdzińskiemu. internetowy Kwartalnik Antymonopolowy i Regulacyjny 5(4), 74-77. doi: 10.7172/IKAR.5.4.6

Welser, I. and Moltioris, S. (2012). The Scope of Arbitration Clauses - Or "All Disputes Arising out of or in Connection with this Contract..." Austrian Yearbook on International Arbitration, 17, 19-30.

Wiśniewski, A.W. (2011). Międzynarodowy arbitraż handlowy w Polsce. Status prawny arbitrażu. Warszawa, Poland: Wolters Kluwer Polska.

Wright, J.D. (2006). Antitrust Law and Competition for Distribution. Yale Journal on Regulation, 23(2), 169-208. 